\title{
A comprehensive assessment of MODIS-derived GPP for forest ecosystems using the site-level FLUXNET database
}

\author{
Xuguang Tang ${ }^{1,2} \cdot$ Hengpeng $\mathrm{Li}^{1} \cdot \mathrm{Ni} \mathrm{Huang}^{2} \cdot \mathrm{Xinyan}_{\mathrm{Li}^{1}} \cdot \mathrm{Xibao}_{\mathrm{Xu}}{ }^{1} \cdot$ \\ Zhi Ding ${ }^{3} \cdot$ Jing $\mathrm{Xie}^{4}$
}

Received: 29 January 2015/ Accepted: 5 June 2015/Published online: 20 June 2015

(C) Springer-Verlag Berlin Heidelberg 2015

\begin{abstract}
Accurate and continuous monitoring of forest production is critical for quantifying the dynamics of regional-to-global carbon cycles. MOD17A2 provides high frequency observations of terrestrial gross primary productivity (GPP) and is widely used to evaluate the spatiotemporal variability and responses to changing climate. However, the effectiveness of the Moderate Resolution Imaging Spectroradiometer (MODIS) in measuring GPP is directly constrained by the large uncertainties in the modeling process, specifically for complicated and extensive forest ecosystems. Although there have been plenty of studies to verify the MODIS GPP product with groundbased measurements covering a range of biome types, few have comprehensively validated the performance of MODIS estimates (C5.5) for diverse forests. Thus, this study examined the degree of correspondence between the MODIS-derived GPP and the EC-measured GPP at seasonal and interannual time scales for the main forest ecosystems, encompassing evergreen broadleaf forest
\end{abstract}

Xuguang Tang

xgtang@niglas.ac.cn

$\bowtie$ Hengpeng Li

hpli@niglas.ac.cn

1 Key Laboratory of Watershed Geographic Sciences, Nanjing Institute of Geography and Limnology, Chinese Academy of Sciences, Nanjing 210008, China

2 State Key Laboratory of Remote Sensing Science, Institute of Remote Sensing and Digital Earth, Chinese Academy of Sciences, Beijing 100101, China

3 Institute of Geographic Sciences and Natural Resources Research, Chinese Academy of Sciences, Beijing 100101, China

4 Department of Geography, University of Zurich, 8006 Zurich, Switzerland
(EBF), evergreen needleleaf forest (ENF), deciduous broadleaf forest (DBF), and mixed forest (MF) relying on 16 flux towers with a total dataset of 68 site-years. Overall, the site-specific evaluation of multi-year mean annual GPP estimates indicates that the current MODIS product works more significantly for DBF and MF, less for ENF, and least for EBF. Except for the tropical forest, MODIS estimates could capture the broad trends of GPP at an 8-day time scale for the other sites. At the seasonal time scale, the highest performance was observed in ENF, followed by $\mathrm{MF}$ and DBF, and the least performance was observed in EBF. Trend analyses also revealed the weak performance in EBF and DBF. This study suggested that current MODIS GPP estimates still need to improve the quality of different upstream inputs in addition to the algorithm for accurately quantifying forest production.

Keywords MOD17A2 - Forest ecosystem · Grow primary production $\cdot$ Assessment

\section{Introduction}

The gross primary productivity (GPP) of forest ecosystem is the largest and most important component of global carbon cycles that provides a link between terrestrial biosphere and the atmosphere (Zhao et al. 2006; Beer et al. 2010; Pourtaghi et al. 2015). This is because it quantifies the transformation of light energy to terrestrial $\mathrm{CO}_{2}$ assimilation through photosynthesis. Our understanding of forest production and its responses to climate variability is critical to evaluations of ecosystem vulnerability and adaptation potentials (Zhao and Running 2010; Sjöström et al. 2013; Pan et al. 2014), specifically in the context of the changing global environment. Terrestrial GPP also 
contributes significantly to human welfare through the provision of food, fiber, and wood production.

Satellite remote sensing provides a repeated, consistent estimate of terrestrial GPP across broad temporal and spatial scales and has advanced tremendously over the past decades. A large number of models have been proposed to quantify the variability in GPP. There are three major approaches to monitoring terrestrial primary production: light use efficiency models (Running et al. 2004; Coops et al. 2007; Sims et al. 2008; Yuan et al. 2010); empirical models that use remotely sensed data calibrated to in situ eddy covariance (EC) measurements (Rahman et al. 2005; Wu et al. 2010, 2011); and machine-learning algorithms, which are also calibrated to in situ observations (Yang et al. 2007; Xiao et al. 2010). However, these models are based on relatively small datasets, and few have explicitly examined both the spatial and temporal variations in remotely sensed proxies and modeled estimates with measurements of GPP (Verma et al. 2014).

Since 2000, satellite-based GPP products have been produced continuously using data from the Moderate Resolution Imaging Spectroradiometer (MODIS) with a temporal resolution of 8 days and a spatial resolution of $1 \mathrm{~km}$ across the globe (Running et al. 2004). Currently, the MOD17A2 product has been improved from collection 4.5 (C4.5) to collection 5 (C5) considering the problems with algorithm and input data (Zhao et al. 2006; Chasmer et al. 2009). Ultimately, the effectiveness and value of such a dataset is determined by the capacity to quantify and explain uncertainties in the MODIS estimates. To meet this end, a global ground-based monitoring network of micrometeorological tower sites (FLUXNET) is in place that uses EC fluxes to estimate site-level GPP as the sum of net ecosystem production (NEP) and ecosystem respiration (Turner et al. 2003; Coops et al. 2007). The FLUXNET community throughout the world has been operating for several years, and it has enabled scientists to assess satellite-based GPP at different time scales across different terrestrial ecosystems encompassing forest, grassland, cropland, and desert (Verma et al. 2014). However, evaluating the differences in the modeled and measured GPP is a challenging task because of the large variation in terrestrial productivity with diverse soil, climate, and vegetation characteristics, as well as the scale mismatch with satellite data.

Although plenty of studies have verified the capacity of MODIS GPP with ground-based measurements covering a range of biome types and proposed many useful strategies to reduce uncertainties (Heinsch et al. 2006; Wang et al. 2013; Pan et al. 2014), there has been few evaluations of MODIS GPP (C5) until now. Sjöström et al. (2013) found that this product underestimated GPP across many sites, most significantly in the dry areas. Moreover, forests cover approximately $30 \%$ of the Earth's total land area and account for $75 \%$ of terrestrial GPP with a great number of forest types (FAO 2010). Nonetheless, previous studies usually focused on a single site or an individual forest type (Gebremichael and Barros 2006; Coops et al. 2007; Propastin et al. 2012), and few have comprehensively validated the performance of MODIS GPP estimates for diverse forests. Therefore, the primary objectives of this study were as follows:

1. How does the MODIS-derived GPP (C5) perform at seasonal to interannual time scales for forest ecosystems, including evergreen broadleaf forest (EBF), evergreen needleleaf forest (ENF), deciduous broadleaf forest $(\mathrm{DBF})$, and mixed forest $(\mathrm{MF})$ ?

2. How well can the MODIS GPP product capture the interannual trend for the main forest types?

The coefficient of determination $\left(R^{2}\right)$, root mean square error (RMSE), and relative error (RE) are used to evaluate how well MODIS GPP estimates can explain the variation in measurements of GPP. These analyses will be useful in improving the accuracy of the satellite-derived MODIS GPP product and enhancing services on ecological science, land management, and environmental policy.

\section{Study materials and methods}

\section{FLUXNET data}

Analysis in this study is based on weekly data from 16 flux towers, which give a total of 68 site-years of data across different forest types with widely disparate climate conditions (Fig. 1). These forest types include EBF, ENF, DBF, and MF (Table 1). Most of these forests are temperate and boreal with diverse species composition, encompassing hardwoods, conifers, and mixed woods with dissimilar soils, hydrological patterns, and stand ages. Other flux sites involve two tropical rain forests situated near the equator. Temperate and boreal forests in the Northern Hemisphere are considered important storage areas for sequestrating atmospheric $\mathrm{CO}_{2}$, which may help in understanding the "missing carbon sink" of Earth (Houghton et al. 1999; Pan et al. 2011; Graven et al. 2013; Pourtaghi et al. 2015). Furthermore, only a small amount of scientific data and literature exist on Africa compared with those on North America, Europe, and Asia owing to sparse and limited eddy covariance sites and long-term ecological research stations (Williams et al. 2008; Sjöström et al. 2013), which leads to a poor understanding of vegetation productivity and its responses to climate variability in African ecosystems until now. Thus, this study systematically compared the performance of MODIS GPP with EC-measured GPP at 


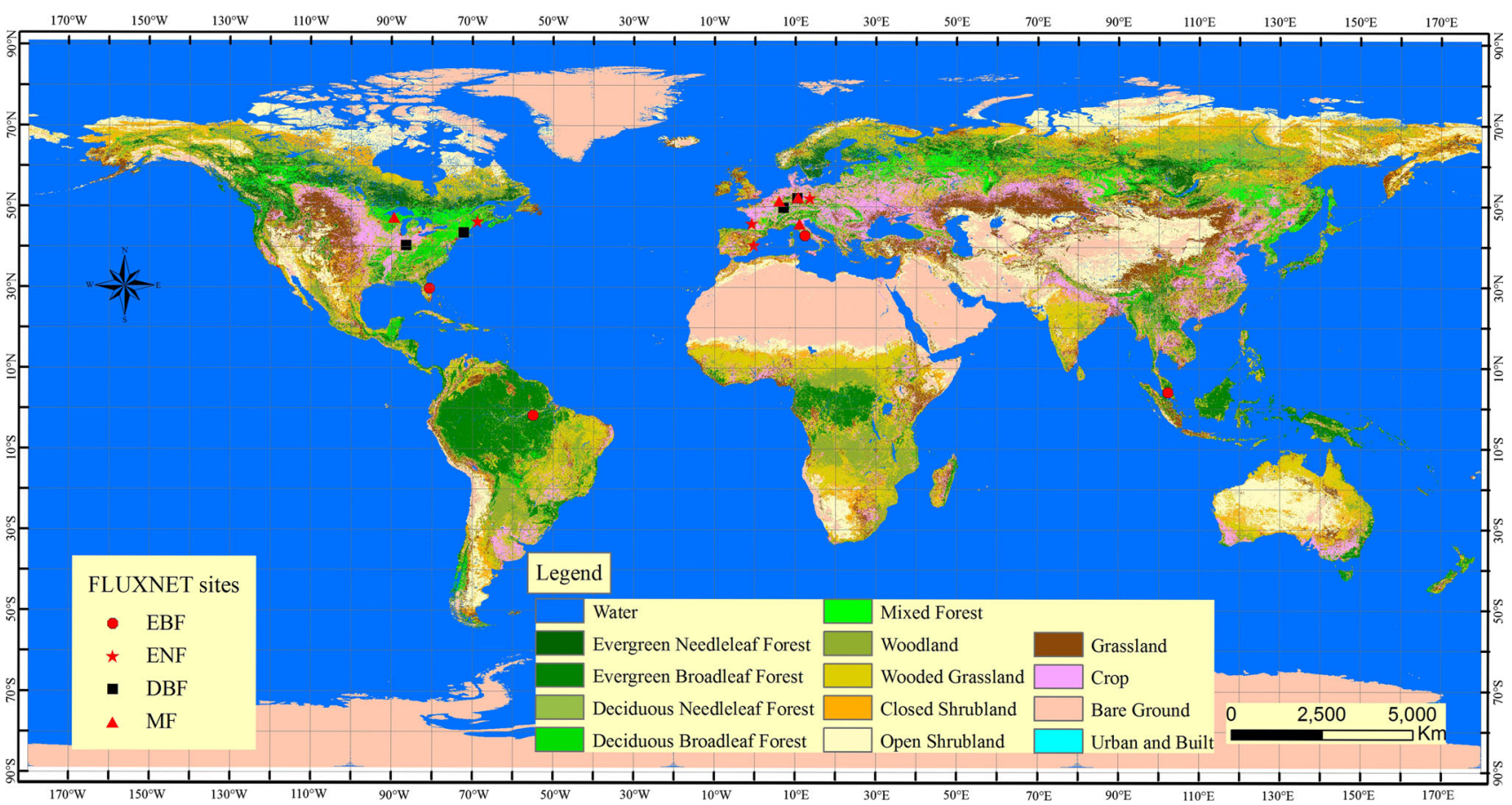

Fig. 1 Geographic locations of the FLUXNET sites. The global land cover classification data are downloaded from http://www.landcover.org/ data/landcover/index.shtml

Table 1 Characteristics of the FLUXNET sites used in this study

\begin{tabular}{llllllll}
\hline Site code & Longitude & Latitude & Forest type & LAI & Age & Year used & References \\
\hline Br-Sa1 & $54.959 \mathrm{~W}$ & $2.857 \mathrm{~S}$ & Evergreen broadleaf forest & 5.3 & Old-growth & $2002-2004$ & Grant et al. (2009) \\
JP-PSO & $102.3 \mathrm{E}$ & $2.967 \mathrm{~N}$ & Evergreen broadleaf forest & 6.5 & - & $2004-2006$ & Saigusa et al. (2008) \\
US-KS2 & $80.671 \mathrm{~W}$ & $28.608 \mathrm{~N}$ & Evergreen broadleaf forest & 2.1 & 16 & $2004-2006$ & Seiler et al. (2009) \\
IT-Cpz & $12.377 \mathrm{E}$ & $41.705 \mathrm{~N}$ & Evergreen broadleaf forest & 3.5 & 38 & $2001-2008$ & Garbulsky et al. (2008) \\
ES-ES1 & $0.319 \mathrm{~W}$ & $39.346 \mathrm{~N}$ & Evergreen needleleaf forest & 2.6 & $\sim 100$ & $2004-2006$ & Reichstein et al. (2005) \\
FR-LBr & $0.769 \mathrm{~W}$ & $44.717 \mathrm{~N}$ & Evergreen needleleaf forest & 4.8 & 44 & $2006-2008$ & Berbigiera et al. (2001) \\
US-Ho1 & $68.740 \mathrm{~W}$ & $45.204 \mathrm{~N}$ & Evergreen needleleaf forest & 5.6 & 109 & $2002-2004$ & Richardson et al. (2012) \\
DE-Tha & $13.567 \mathrm{E}$ & $50.964 \mathrm{~N}$ & Evergreen needleleaf forest & 4.8 & 120 & $2001-2008$ & Grünwald and Bernhofer (2007) \\
US-MMS & $86.413 \mathrm{~W}$ & $39.323 \mathrm{~N}$ & Deciduous broadleaf forest & 4.1 & 70 & $2004-2006$ & Dragoni et al. (2011) \\
US-Ha1 & $72.172 \mathrm{~W}$ & $42.538 \mathrm{~N}$ & Deciduous broadleaf forest & 4.7 & $75-110$ & $2004-2006$ & Blonquist et al. (2010) \\
DE-Hai & $10.452 \mathrm{E}$ & $51.079 \mathrm{~N}$ & Deciduous broadleaf forest & 4.8 & $\sim 250$ & $2004-2006$ & Knohl et al. (2003) \\
FR-Hes & $7.066 \mathrm{E}$ & $48.674 \mathrm{~N}$ & Deciduous broadleaf forest & 5.7 & 35 & $2001-2008$ & Granier et al. (2002) \\
IT-Non & $11.088 \mathrm{E}$ & $44.690 \mathrm{~N}$ & Mixed forest & 1.8 & 15 & $2006-2008$ & Carvalhais et al. (2010) \\
US-Syv & $89.347 \mathrm{~W}$ & $46.242 \mathrm{~N}$ & Mixed forest & 4.1 & Old-growth & $2002,2005-2006$ & Desai (2010) \\
DE-Meh & $10.655 \mathrm{E}$ & $51.275 \mathrm{~N}$ & Mixed forest & - & $\sim 4$ & $2004-2006$ & Don et al. (2009) \\
BE-Vie & $5.997 \mathrm{E}$ & $50.305 \mathrm{~N}$ & Mixed forest & 5.1 & 120 & $2001-2008$ & Aubinet et al. (2002) \\
\hline
\end{tabular}

The names of flux sites are abbreviations from the FLUXNET community

seasonal and interannual time scales for the major forest ecosystems on Earth.

Flux towers are designed with standard measurement protocols, data quality control, and storage systems and form a global network called FLUXNET to reduce the uncertainty associated with site-to-site variation in flux measurements and calculations and to make comparisons between sites (Beer et al. 2010; Verma et al. 2014). The FLUXNET level 4 product provides measurements of the canopy-scale water vapor flux, $\mathrm{CO}_{2}$ flux, meteorological 
variables, and estimates of GPP as the residual of the measured NEE and modeled ecosystem respiration using an empirical temperature response function (Reichstein et al. 2005). The temperature response function is calibrated using nighttime data when winds are usually low and assumes that the calibrated relationship holds during the daytime (Lloyd and Taylor 1994). The NEE is gapfilled using the artificial neural network (ANN) method or the marginal distribution sampling (MDS) method (Papale and Valentini 2003; Reichstein et al. 2005). In this study, we used the standardized GPP data calculated from the NEE filled using the MDS approach. For each flux site, at least 3 years of data were obtained to reduce the uncertainty of year-to-year variations. In addition, up to eightyear data of the typical flux site for the main forest types were used for interannual trend analyses.

\section{MODIS product}

Currently, there are two types of MODIS GPP datasets. The first is the improved Collection 5 MODIS GPP data generated by NTSG using the NCEP/DOE II reanalysis as the driving meteorological database, and the second is NASA's near real-time MODIS GPP data contaminated by cloudiness, which should not be used for research purposes. Therefore, the verification exercise is based on the NTSG MOD17A2 dataset (C5.5), which is available from the University of Montana http://www.ntsg.umt.edu/project/ mod17. The daily MODIS GPP is calculated according to the following algorithm:

$\mathrm{GPP}=\varepsilon_{\max } \times 0.45 \times \mathrm{SW}_{\text {rad }} \times \mathrm{FPAR} \times \mathrm{fVPD} \times \mathrm{fT}_{\text {min }}$,

where $\varepsilon_{\max }$ is the maximum light use efficiency; $\mathrm{SW}_{\text {rad }}$ is the short-wave downward solar radiation, of which $45 \%$ is photosynthetically active radiation (PAR); FPAR is the fraction of PAR being absorbed by the plants; and fVPD and $\mathrm{fT}_{\min }$ are the reduction scalars from water stresses and low temperature, respectively. The MOD17A2 GPP product used in this study implements 6-h National Center for Environmental Prediction/Department of Energy (NDEP/ DOE) reanalysis II data, including the daily minimum temperature $\left(T_{\min }\right)$, daytime temperature $\left(T_{\text {day }}\right)$, daily average temperature ( $\left.T_{\text {avg }}\right)$, daily vapor pressure, and daily total $\mathrm{SW}_{\text {rad }}$. The NCEP/DOE II data were found to be capable of capturing major changes in the surface climate anomalies (Betts et al. 2006). The fraction of photosynthetically active radiation (FPAR) in the algorithm is derived from the 8-day MOD15A2 $1 \mathrm{~km}$ product. To map biome-specific physiological parameters $\left[\varepsilon_{\max }\right.$, minimum and maximum temperature, and vapor pressure saturation deficit (VPD)] using a Biome Properties Look-Up
Table (BPLUT), the $1 \mathrm{~km}$ University of Maryland (UMD) land cover classification scheme in the MOD12Q1 product was used. Data from an area of $3 \mathrm{~km} \times 3 \mathrm{~km}$ MODIS GPP cells centered on each flux site were used in the analysis to represent the tower footprint. Extracting a $3 \times 3$ window for comparison with site data prevents potential errors in the georectification of satellite data. For a detailed discussion of the issue of georectification when comparing site-level data with satellite-based products, please see Heinsch et al. (2006) and Propastin et al. (2012). In addition, we determined the quality of the value of each pixel within the area using the quality assurance (QA) flags included in the product and only used the GPP estimates of good quality.

\section{Results}

\section{Site-specific evaluation of multi-year mean annual MODIS GPP product}

Figure 2 illustrates the multi-year mean annual MOD17A2 $\mathrm{GPP}\left(\mathrm{GPP}_{\mathrm{MOD}}\right)$ and flux tower GPP $\left(\mathrm{GPP}_{\mathrm{EC}}\right)$ at all 16 flux sites. The site-specific comparison showed a generally good agreement across the sites with $R^{2}=0.60$, $\mathrm{RMSE}=1.26 \mathrm{~g} \mathrm{C} \mathrm{m}^{-2} \mathrm{day}^{-1}$, and $\mathrm{RE}=20.7 \%$. However, as shown in Fig. 2, the MODIS GPP product of IT$\mathrm{Cpz}$ and US-KS2 that belongs to evergreen broadleaf forest significantly overestimated the vegetation production but severely underestimated GPP at the tropical rain forest site $\mathrm{Br}-\mathrm{Sa} 1$. For the majority of sites belonging to ENF, DBF,

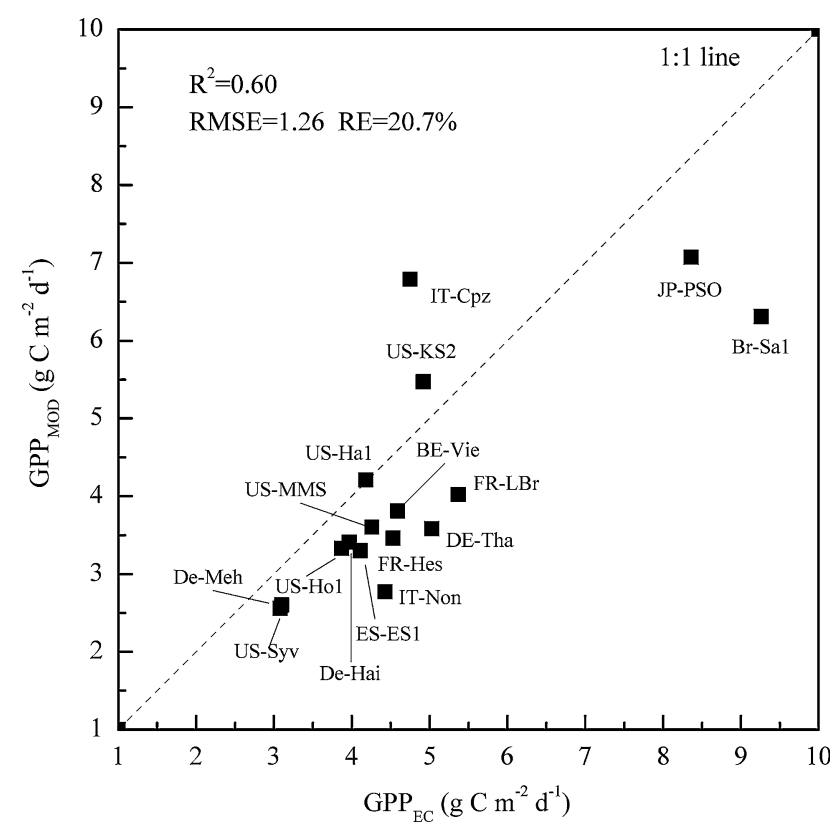

Fig. 2 Comparisons of multi-year mean annual MOD17A2 GPP $\left(\mathrm{GPP}_{\mathrm{MOD}}\right)$ and flux tower GPP $\left(\mathrm{GPP}_{\mathrm{EC}}\right)$ at all 16 sites 
and MF, the MODIS algorithm usually underestimated GPP with a relatively small difference. Statistically, the mean relative deviations of $\mathrm{ENF}, \mathrm{DBF}$, and $\mathrm{MF}$ were $-21.94,-13.48$, and $-19.86 \%$, respectively. All of these forest sites represented a considerable variation in location, climate, stand age, and species composition; meanwhile, a multi-year mean annual GPP can avoid the effect of yearto-year fluctuations. Therefore, it indicated that the current MODIS GPP product works well for deciduous broadleaf forest and mixed forest, is average for evergreen needleleaf forest, and still finds it difficult to capture the dynamics of GPP in evergreen broadleaf forest.

\section{Comparison of seasonal and interannual variations between time-series MODIS GPP with EC- measured GPP}

This study also compared time-series of the MODIS GPP and EC-measured GPP at both 8-day and interannual time scales for the major forest ecosystems including $\mathrm{EBF}$, $\mathrm{ENF}, \mathrm{DBF}$, and $\mathrm{MF}$, to determine the underlying reasons for the performance of the multi-year mean annual GPP values at the 16 flux sites. Figure 3 illustrates seasonal traces of GPP estimated from the tower $\mathrm{CO}_{2}$ flux data and MODIS GPP, and Fig. 4 shows the scatter plots between the MODIS GPP and tower GPP on an 8-day time scale. As shown in Figs. 3 and 4, the RMSE was largest in EBF (2.78 $\left.\mathrm{g} \mathrm{C} \mathrm{m}^{-2} \mathrm{day}^{-1}\right)$, followed by DBF $\left(2.47 \mathrm{~g} \mathrm{C} \mathrm{m}^{-2}\right.$ day $^{-1}$ ) and $\mathrm{MF}\left(1.92 \mathrm{~g} \mathrm{C} \mathrm{m}^{-2} \mathrm{day}^{-1}\right)$, while it was the smallest in ENF $\left(1.75 \mathrm{~g} \mathrm{C} \mathrm{m}^{-2}\right.$ day $\left.^{-1}\right)$. The large bias in GPP estimates for tropical rain forest (TRF) led to the highest RMSE for EBF. The seasonal dynamics in the time-series MODIS GPP and EC-measured GPP at BRSa1 and JP-PSO also fluctuated severally nearly year round, showing that the MODIS estimates are inapplicable to TRF. However, with the exception of tropical forests, the MODIS product could capture the broad trends of GPP at both US-KS2 and IT-Cpz flux sites despite the apparent overestimation during growing season at IT-Cpz. A slight underestimation existed in the summertime at all sites for ENF and MF. Nevertheless, the MODIS product showed a good performance in capturing the corresponding GPP variations. The eight-day MODIS GPP and EC-measured GPP were distributed closely around the 1:1 line. As for DBF, seasonal traces and scatter plots at all flux sites showed an overestimation during the transition seasons of spring and autumn, but a significant underestimation was observed at the peak of the vegetation period. Meanwhile, we found that the residuals were not randomly distributed. In absolute magnitude, low GPP values were generally in accordance with low prediction errors, whereas high GPP values were greatly underestimated.
Then, we also analyzed how the MODIS GPP agreed with EC-measured GPP at an interannual time scale for the main forest types with the 68 site-year dataset. For each forest type, 17 years of eddy covariance GPP and MODIS GPP product were obtained. Figure 5 illustrates the scatterplots between the annual mean GPP estimates from the flux tower sites and the MODIS GPP product for EBF, ENF, DBF, and MF. The best performance was in $\mathrm{DBF} \quad\left(\mathrm{RMSE}=0.94 \mathrm{~g} \mathrm{C} \mathrm{m}^{-2} \mathrm{day}^{-1} ; \quad \mathrm{RE}=16.6 \%\right)$, followed by $\mathrm{MF}$ (RMSE $=0.95 \mathrm{~g} \mathrm{C} \mathrm{m}^{-2}$ day $^{-1} ; \mathrm{RE}=$ $20.34 \%$ ) and $\mathrm{ENF}$ ( $\mathrm{RMSE}=1.25 \mathrm{~g} \mathrm{C} \mathrm{m}^{-2} \mathrm{day}^{-1}$; $\mathrm{RE}=24.08 \%$ ), while it was the worst in $\mathrm{EBF}$ ( $\mathrm{RMSE}=$ $2.01 \mathrm{~g} \mathrm{C} \mathrm{m}^{-2}$ day $^{-1} ; \mathrm{RE}=31.27 \%$ ). This result can be explained by the transfer of bias from seasonal predictions of GPP. Nevertheless, the MODIS estimates are insensitive to the large vegetation production of DBF with a significant underestimation.

\section{Analysis of the interannual trend captured by MODIS GPP and EC-measured GPP}

Recently, several studies have been conducted to monitor and predict the terrestrial primary production of the entire Earth and also to explore possible responses to a changing climate and environment (Zhao and Running 2010; Pan et al. 2014). However, plenty of uncertainties associated with the model and the data still existed. This study evaluated the interannual trend captured by the annual mean GPP estimates inferred from eddy covariance data and by the MOD17A2 GPP product for the typical flux site of each forest type. As shown in Fig. 6, the MODIS GPP of mixed forest at the BE-Vie flux site has the best performance among all sites. The tendencies of MODIS GPP and ECmeasured GPP were consistent with relatively small differences. The performance of GPP estimates in the ENFDE-Tha site was moderate, accompanied by an apparent underestimation during these years. The MODIS algorithm had the weakest performance in the EBF-IT-Cpz and DBF-FR-Hes sites. Nonetheless, this algorithm showed a persistent overestimation of vegetation production for the IT-Cpz site, specifically in recent years. By contrast, the algorithm consistently underestimated the trend of GPP with slight variations and cannot capture the drastic eddy covariance GPP dynamics at the FR-Hes site.

\section{Discussion}

A validation campaign is an important task of satellitebased GPP product because it can evaluate the performance at different temporal and spatial scales. In this study, the degree of correspondence between the EC-measured GPP and that estimated by the MODIS operational algorithm, 


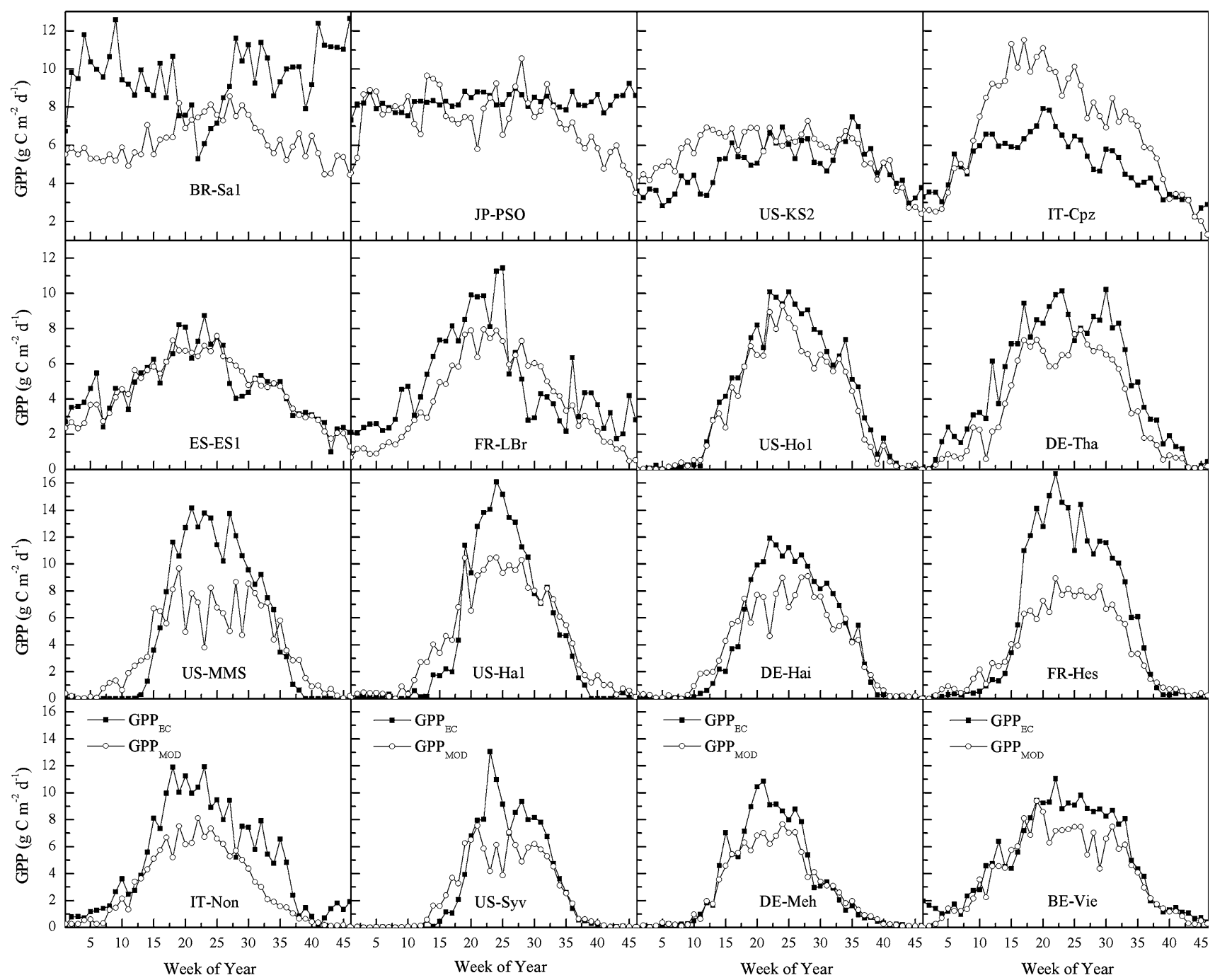

Fig. 3 Seasonal traces of GPP estimated from tower $\mathrm{CO}_{2}$ flux data $\left(\mathrm{GPP}_{\mathrm{EC}}\right)$ and MODIS GPP (GPP $\mathrm{MOD}$ ) on an 8-day time scale for the 16 flux sites including evergreen broadleaf forest (EBF), evergreen needleleaf forest (ENF), deciduous broadleaf forest (DBF), and mixed forest (MF)

which used general biome-specific physiological parameters, broad-scale meteorological data, and other upstream inputs including LAI and FPAR, was examined. Differences in both the MODIS-derived GPP and EC-measured GPP were compared at seasonal and interannual time scales for major forest ecosystems, including EBF, ENF, DBF, and MF. Yet, there still existed a number of possible reasons for the differences in the tower and MODIS estimates of GPP. Therefore, uncertainties from both the MODIS-derived GPP and EC-measured GPP were analyzed for the purpose of accurately monitoring the forest production.

\section{Biophysical variability of $\varepsilon$}

As a proxy of the conversion efficiency of the incident radiation in $\mathrm{PAR}, \varepsilon$ varies widely with plant functional types (Turner et al. 2003). This variability in $\varepsilon$ is also attributed to sub-optimal climatic conditions. To quantify the biome- and climate-induced ranges of $\varepsilon$, the MOD17A2 product computed the light use efficiency with a complex ecosystem model (Biome-BGC) and generated BPLUT that contained parameters for temperature and VPD limits as well as specific leaf area and respiration coefficients for representative vegetation types (Running et al. 2004). However, only minor biome types were defined. Despite the wide range of climatic conditions and associated stand structures, soil types, and ages, the same $\varepsilon$ was applied indiscriminately, thus introducing large uncertainties into the estimates of GPP (Sjöström et al. 2013). The MODIS GPP algorithm suggests simple linear ramp function of climatic variables to calculate the scalars that attenuate the potential $\varepsilon$ to produce the final $\varepsilon$ used to predict GPP (Turner et al. 2003; Heinsch et al. 2006). However, a 
Fig. 4 Comparisons between tower GPP $\left(\mathrm{GPP}_{\mathrm{EC}}\right)$ and MODIS GPP (GPP $\left.\mathrm{GOD}_{\mathrm{MO}}\right)$ on an 8-day time scale for the major forest types including evergreen broadleaf forest (EBF), evergreen needleleaf forest (ENF), deciduous broadleaf forest (DBF), and mixed forest (MF). In addition, TRF refers to tropical rain forest here
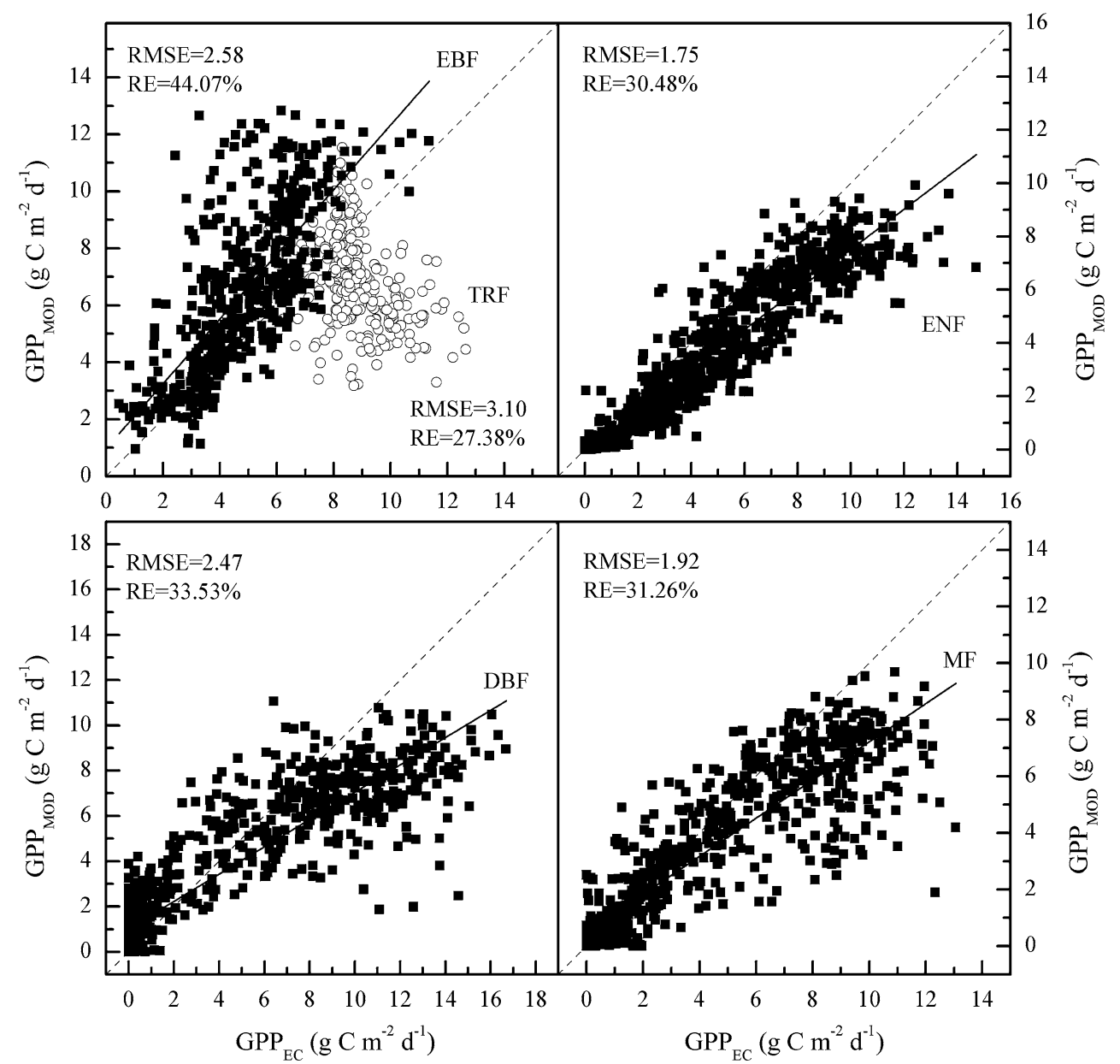

number of studies have concluded that the light use efficiency rate is also dependent on incoming solar radiation and saturates on days with clear sky conditions and a high amount of PAR (Turner et al. 2003; Lagergren et al. 2005). The current BPLUT cannot meet the needs of accurately defining $\varepsilon$, especially for complex and diverse forest ecosystems. Propastin et al. (2012) also revealed the disadvantage of using MOD17A2 to estimate the GPP of a moist tropical rain forest in Indonesia and indicated that the $\varepsilon_{\text {max }}$ value for evergreen broadleaf forest is not applicable.

\section{Meteorological data}

Meteorological data from the NASA Data Assimilation Office (DAO) are based on a general circulation model that is continuously assimilating observations from space and ground stations with a spatial resolution of $1^{\circ}$ by $1.25^{\circ}$. In the C4 MOD17 algorithm, each $1 \mathrm{~km}$ pixel falling into the same DAO grid will inherit the same meteorological data and create a noticeable footprint. Such treatment may cause large inaccuracies at the local scale, specifically for terrain with topographical variation or located at relatively abrupt climatic gradient zones. To solve this problem, Zhao et al. (2006) spatially interpolated the coarse resolution DAO data to the resolution of a $1-\mathrm{km}$ pixel using a non-linear interpolation scheme. The NCEP/DOE reanalysis II data are an improved version of the daily driving meteorological dataset, which can fix errors and update parameterizations of physical processes (Kanamitsu et al. 2002). However, the analysis of this meteorological data used in the MODIS GPP algorithm still showed some apparent differences when compared with tower measurements because the initial coarse spatial resolution data were shown to include biases (Heinsch et al. 2006; Kanniah et al. 2009; Wang et al. 2013). The temperature and VPD were found to be underestimated, whereas radiation from the reanalysis data generally contains large uncertainties, specifically in areas with high spatial and temporal variability in cloud cover (Sjöström et al. 2013). The large uncertainties or low quality of the MODIS GPP to capture ground-based measurements for tropical rain forests is also expected as (1) severe contamination from cloudiness and aerosol effects (inherent issue) plus the saturation issue of vegetation indexes, which is demonstrated by the heated debate on 
Fig. 5 Comparisons of annual mean GPP estimates from the flux tower sites $\left(\mathrm{GPP}_{\mathrm{EC}}\right)$ and the MODIS GPP product ( $\mathrm{GPP}_{\mathrm{MOD}}$ ) for the main forest types including evergreen broadleaf forest (EBF), evergreen needleleaf forest (ENF), deciduous broadleaf forest (DBF), and mixed forest (MF)

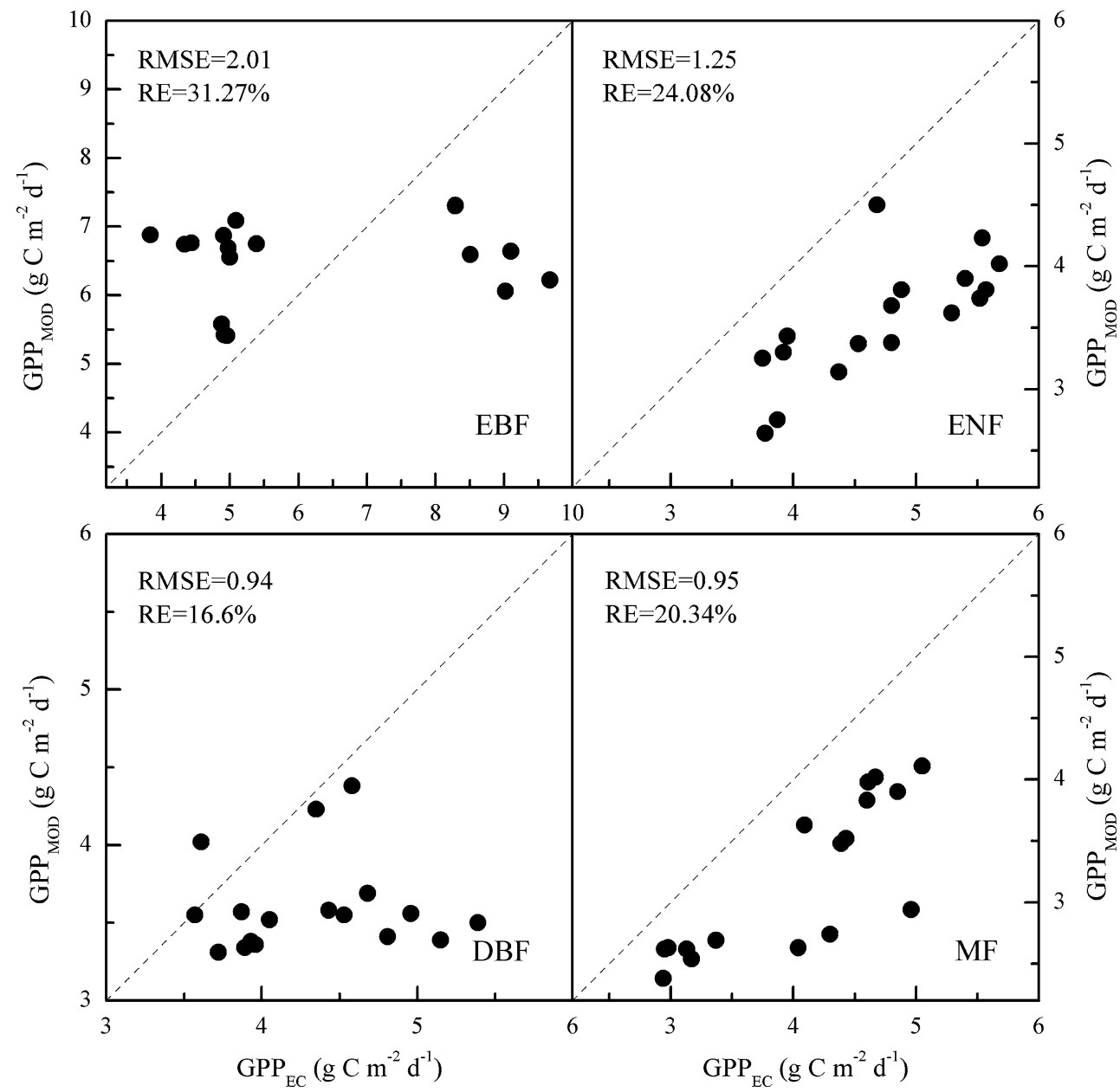

"green-up" or "browning down" EVI of the Amazon in response to the 2005 drought (Zhao and Running 2010); (2) tropical areas have a much lower weather station coverage, and thus global meteorological reanalysis datasets have poor constraints (Zhao and Running 2011); and (3) smallscale convection dominates atmospheric processes in the tropics, and the convection scale is too small for coarse resolution reanalysis systems to render in detail (Kerr 2011).

\section{LAI and FPAR uncertainty}

Similarly, terrestrial primary production is not directly calculated from remote sensing measurements but is modeled as a function of LAI and FPAR with the MOD15 algorithm. These indices used to estimate terrestrial GPP are contaminated by atmospheric characteristics that would send misleading signals to satellite sensors (Huete et al. 2002; Huang et al. 2014). Therefore, creating a composite of LAI and FPAR is required to provide an accurate depiction of global leaf area dynamics that includes the consideration of spectral cloud contamination, particularly in the tropics. In addition, both of these vegetation indices are derived using only red and near-infrared reflectance. However, recent studies have shown that forest areas with high biomass, such as humid tropical rainforests, are generally characterized by a weaker sensitivity of the canopy signal to LAI in remote sensing data (Foody et al. 2001, 2003; Huete et al. 2008), and the high amount of biomass caused a rapid saturation of the canopy radiation signal. These analyses demonstrate that the MOD17 algorithm does not account for the saturation of gross primary photosynthesis on an 8-day time scale. Moreover, flux sites usually measure LAI of the dominant overstory canopy, whereas the MODIS sensor receives reflectance information for a vertically and horizontally integrated canopy. If the dominant canopy is open, as it is at many of these sites, the MOD15 algorithm will consider both the overstory and understory surface reflectance as a single canopy unit of the land cover classification, leading to an overestimation of LAI relative to site-based measurements (Heinsch et al. 2006). At the DBF sites, the understory may flush out earlier in the springtime (Fig. 3). In addition, if the forest also contains evergreen needleleaf trees, such as US-Ha1, 
Fig. 6 Assessment of interannual trend of annual mean GPP estimates inferred from eddy covariance data $\left(\mathrm{GPP}_{\mathrm{EC}}\right)$ and MOD17A2 GPP product $\left(\mathrm{GPP}_{\mathrm{MOD}}\right)$ for the typical flux site for each forest type

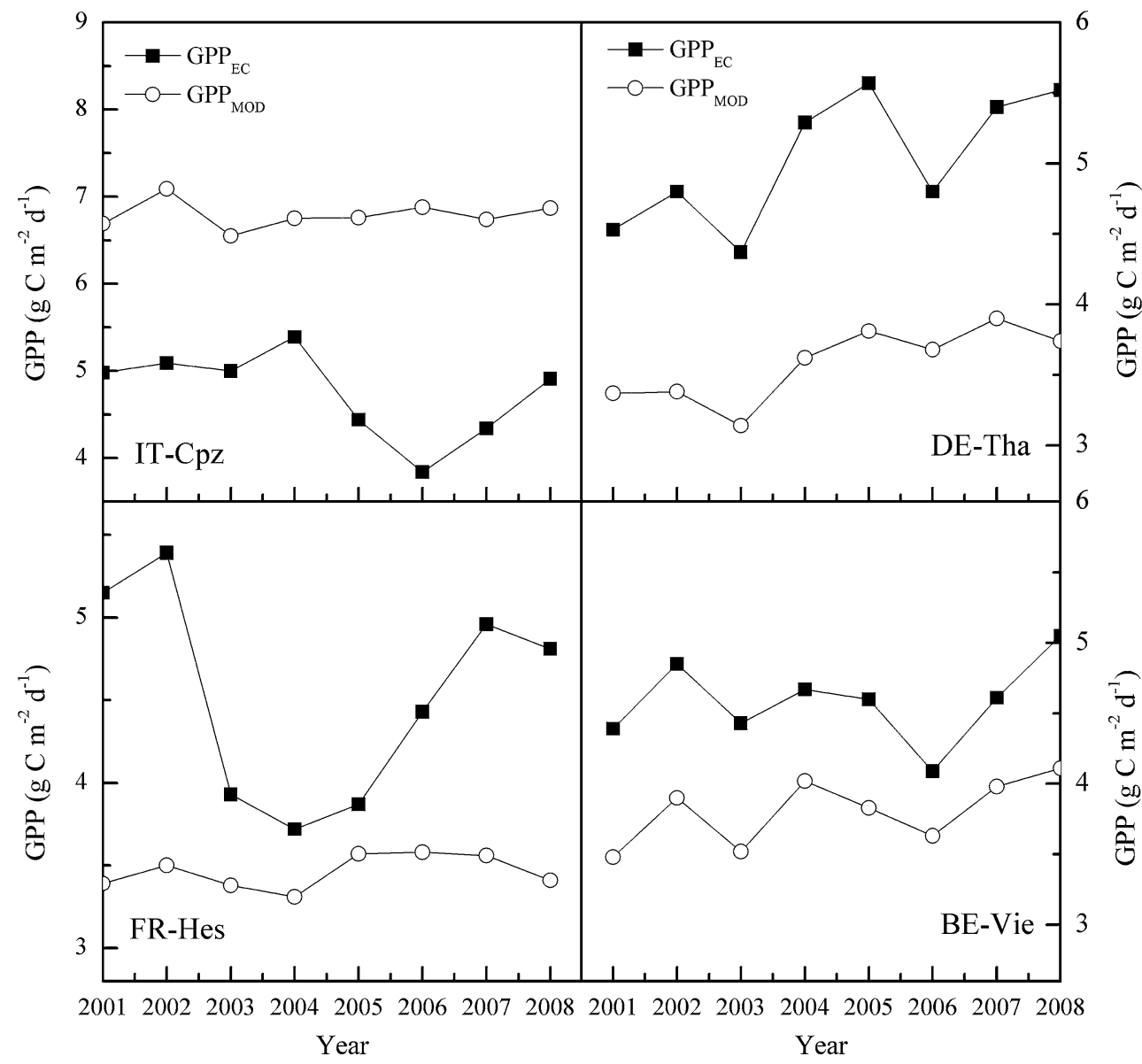

the algorithm will calculate an LAI and FPAR for a DBF forest canopy prior to actual leaf-out. At EBF sites including US-KS2 and IT-Cpz, both the understory and overstory LAI were measured in the field and the MOD15 LAI greatly overestimated the total LAI of these sites, suggesting that sites with open canopies should consider the understory contribution to the estimation of LAI and GPP.

\section{Land cover classification}

Accurate land cover classification from the MOD12Q1 decision tree algorithm is also vital to the success of MODIS GPP calculations (Heinsch et al. 2006). Propagation of error must also be considered. The associated fraction of the photosynthetically active radiation absorbed by vegetation canopies (FPAR) algorithm uses a structural land cover classification scheme in its calculations (Myneni et al. 1997), while the GPP algorithm depends upon the UMD land cover classification scheme to differentiate among biome types and determine the corresponding light use efficiency for each pixel. Errors in either of these classification schemes will lead to incorrect estimates of production (Wu et al. 2010; Sjöström et al. 2013). Another problem is that the current $1 \mathrm{~km}$ MODIS global land cover classification unit poses a risk because it may be too coarse for regional applications ( $\mathrm{Li}$ et al. 2014; Pourtaghi et al. 2015). Many mixed pixels occurred and were usually composed of diverse vegetation types, which led to difficulty in the proper description of the variability of biomespecific parameters.

\section{Uncertainty of EC-measured GPP}

The EC measurements themselves are not free from error. EC-measured GPP is estimated as the sum of the daytime NEP and ecosystem respiration, in which the latter is inferred from the nighttime relationship between ECmeasured NEE and the corresponding temperature (Lloyd and Taylor 1994). It has been noted that because the EC method derives daytime respiration using nighttime fluxtemperature relationships and ignores the reduction in leaf respiration in daylight relative to darkness, the method can consistently overestimate GPP (Reichstein et al. 2005; Coops et al. 2007) and the standard method used might be inappropriate for tropical ecosystems (Archibald et al. 
2009; Sjöström et al. 2013). Furthermore, uncertainties also arise owing to a mismatch in scale between the EC footprint and MODIS data. These uncertainties make the direct comparison of field measurements with MODIS data difficult, particularly in heterogeneous landscapes (Tan et al. 2006; Verma et al. 2014), because retrievals are not ideally centered on the precise location of the pixel used. Particularly in biomes with strong seasonal climates, sub-pixel heterogeneity can produce great biases in remotely sensed phenology (Abbas et al. 2015), which affects both the observed and modeled GPP in many ecosystems. In principle, greater differences might exist when comparing predicted GPP $\mathrm{MOD}_{\mathrm{MO}}$ with $\mathrm{GPP}_{\mathrm{EC}}$ because EC samples only part of the mixed pixel and cannot represent other land cover types within the pixel (Chasmer et al. 2009). Referring to other previous studies (Rahman et al. 2005; Xiao et al. 2010; Tang et al. 2013), the average values for the central $3 \mathrm{~km} \times 3 \mathrm{~km}$ area from the MODIS product were extracted to better represent the flux tower footprint.

\section{Conclusion}

Despite these uncertainties, the study presented here indicated that satellite-based estimates of MODIS GPP provided a relatively accurate observations compared to the EC-measured GPP for most forest types. The quality of the MODIS GPP product is ultimately controlled by the quality of different upstream inputs, strengths, and weaknesses of the algorithm and uncertainties in the biome property parameters. Nevertheless, given the extensive land area occupied by forest ecosystems on Earth, the current MODIS-derived GPP still needs to improve its reliability in the ongoing monitoring of terrestrial ecosystems and the provision of continuous measurements of forest production.

Acknowledgments This study was jointly supported by the "135" Key Project of Nanjing Institute of Geography and Limnology, CAS (NIGLAS2012135005), the Open Fund of State Key Laboratory of Remote Sensing Science (OFSLRSS201502), and the Natural Science Foundation of Jiangsu Province, China (BK20141058, BK20141513). We thank the principal investigators and contributors of the improved Collection 5 MODIS GPP data generated by NTSG using NCEP/DOE II reanalysis at the University of Montana. We are also grateful to the EC data sharing provided by the FLUXNET community.

\section{References}

Abbas MR, Bin AB, Abbas TR (2015) Use MODIS satellite data to study new phenomena of underground fire in the Al Ruhban oasis in Al Najaf city, Iraq. Environ Earth Sci 73(7):3475-3485. doi:10.1007/s12665-014-3632-8

Archibald SA, Kirton A, Van der Merwe MR, Scholes RJ, Williams CA (2009) Drivers of inter-annual variability in net ecosystem exchange in a semi-arid savanna ecosystem, South Africa. Biogeosciences 6(2):251-266. doi:10.5194/bgd-5-3221-2008

Aubinet M, Heinesch B, Longdoz B (2002) Estimation of the carbon sequestration by a heterogeneous forest: night flux corrections, heterogeneity of the site and inter-annual variability. Glob Change Biol 8(11):1053-1071. doi:10.1046/j.1365-2486.2002.00529.x

Beer C, Reichstein M, Tomelleri E, Ciais P, Jung M (2010) Terrestrial gross carbon dioxide uptake: global distribution and covariation with climate. Science 329(5993):834-838. doi:10.1126/science. 1184984

Berbigiera P, Bonnefonda JM, Mellmann P (2001) $\mathrm{CO}_{2}$ and water vapour fluxes for 2 years above Euroflux forest site. Agric For Meteorol 108(3):183-197. doi:10.1016/S0168-1923(01)00240-4

Betts AK, Zhao M, Dirmeyer PA, Beljaars ACM (2006) Comparison of ERA40 and NCEP/DOE near-surface data sets with other ISLSCP-II data sets. J Geophys Res (1984-2012). doi:10.1029/ 2006JD007174

Blonquist J, Montzka SA, Yakir D, Desai AR, Dragoni D (2010) The potential of carbonyl sulfide as a tracer for gross primary productivity at flux tower sites. AGU Fall Meeting B21G-07

Carvalhais N, Reichstein M, Ciais P, Collatz GJ, Mahecha MD (2010) Identification of vegetation and soil carbon pools out of equilibrium in a process model via eddy covariance and biometric constraints. Glob Change Biol 16(10):2813-2829. doi:10.1111/j.1365-2486.2010.02173

Chasmer L, Barr A, Hopkinson C, McCaughey H, Treitz P (2009) Scaling and assessment of GPP from MODIS using a combination of airborne lidar and eddy covariance measurements over jack pine forests. Remote Sens Environ 113(1):82-93. doi:10. 1016/j.rse.2008.08.009

Coops NC, Black TA, Jassal RPS, Trofymow JA, Morgenstern K (2007) Comparison of MODIS, eddy covariance determined and physiologically modelled gross primary production (GPP) in a Douglas-fir forest stand. Remote Sens Environ 107(3):385-401. doi:10.1016/j.rse.2006.09.010

Desai AR (2010) Climatic and phenological controls on coherent regional interannual variability of carbon dioxide flux in a heterogeneous landscape. J Geophys Res. doi:10.1029/ 2010JG001423

Don A, Rebmann C, Kolle O, Scherer-Lorenzen M, Schulze ED (2009) Impact of afforestation- associated management changes on the carbon balance of grassland. Glob Change Biol 15(8):1990-2002. doi:10.1111/j.1365-2486.2009.01873.x

Dragoni D, Schmid HP, Wayson CA, Potter H, Grimmond CSB (2011) Evidence of increased net ecosystem productivity associated with a longer vegetated season in a deciduous forest in south-central Indiana, USA. Glob Change Biol 17(2):886-897. doi:10.1111/j.1365-2486.2010.02281.x

FAO (2010) Global forest resources assessment 2010. Food and Agriculture Organization of the United Nations, Rome

Foody GM, Cutler ME, Mcmorrow J, Pelz D, Tangki H (2001) Mapping the biomass of Bornean tropical rain forest from remotely sensed data. Glob Ecol Biogeogr 10(4):379-387. doi:10.1046/j.1466-822X.2001.00248.x

Foody GM, Boyd DS, Cutler ME (2003) Predictive relations of tropical forest biomass from Landsat TM data and their transferability between regions. Remote Sens Environ 85(4):463-474. doi:10.1016/S0034-4257(03)00039-7

Garbulsky MF, Peñuelas J, Papale D, Filella I (2008) Remote estimation of carbon dioxide uptake of terrestrial ecosystems. Glob Change Biol 14(12):2860-2867. doi:10.1111/j.1365-2486. 2008.01684.x

Gebremichael M, Barros AP (2006) Evaluation of MODIS gross primary productivity (GPP) in tropical monsoon regions. Remote Sens Environ 100(2):150-166. doi:10.1016/j.rse.2005.10.009 
Granier A, Pilegaard K, Jensen NO (2002) Similar net ecosystem exchange of beech stands located in France and Denmark. Agric For Meteorol 114(1):75-82. doi:10.1016/S0168-1923(02)00 137-5

Grant RF, Hutyra LR, de Oliveira RC, Munger JW, Saleska SR (2009) Modeling the carbon balance of Amazonian rain forests: resolving ecological controls on net ecosystem productivity. Ecol Monogr 79(3):445-463. doi:10.1890/08-0074.1

Graven HD, Keeling RF, Piper SC, Patra PK, Stephens BB (2013) Enhanced seasonal exchange of $\mathrm{CO}_{2}$ by northern ecosystems since 1960. Science 341(6150):1085-1089. doi:10.1126/science. 1239207

Grünwald T, Bernhofer C (2007) A decade of carbon, water and energy flux measurements of an old spruce forest at the Anchor Station Tharandt. Tellus B 59(3):387-396. doi:10.1111/j.16000889.2007.00259.x

Heinsch FA, Zhao M, Running SW, Kimball JS, Nemani RR (2006) Evaluation of remote sensing based terrestrial productivity from MODIS using regional tower eddy flux network observations. IEEE T Geosci Remote 44(7):1908-1925. doi:10.1109/TGRS. 2005.853936

Houghton RA, Hackler JL, Lawrence KT (1999) The US carbon budget: contributions from land-use change. Science 285(5427): 574-578. doi:10.1126/science.285.5427.574

Huang CC, Li YM, Yang H, Sun DY, Yu ZY, Zhang Z, Chen X, Xu LJ (2014) Detection of algal bloom and factors influencing its formation in Taihu lake from 2000 to 2011 by MODIS. Environ Earth Sci 71(8):3705-3714. doi:10.1007/s12665-013-2764-6

Huete A, Didan K, Miura T, Rodriguez EP, Gao X (2002) Overview of the radiometric and biophysical performance of the MODIS vegetation indices. Remote Sens Environ 83(1-2):195-213. doi:10.1016/S0034-4257(02)00096-2

Huete AR, Restrepo-Coupe N, Ratana P, Didan K, Saleska SR (2008) Multiple site tower flux and remote sensing comparisons of tropical forest dynamics in Monsoon Asia. Agric For Meteorol 148(5):748-760. doi:10.1016/j.agrformet.2008.01.012

Kanamitsu M, Ebisuzaki W, Woollen J, Yang SK, Hnilo JJ (2002) NCEP-DOE AMIP-II REANALYSIS (R-2). B Am Meteorol Soc 83(11):1631-1643. doi:10.1175/BAMS-83-11-1631

Kanniah KD, Beringer J, Hutley LB, Tapper NJ, Zhu X (2009) Evaluation of Collections 4 and 5 of the MODIS Gross Primary Productivity product and algorithm improvement at a tropical savanna site in northern Australia. Remote Sens Environ 113(9):1808-1822. doi:10.1016/j.rse.2009.04.013

Kerr RA (2011) Vital details of global warming are eluding forecasters. Science 334(6053):173-174. doi:10.1126/science. 334.6053 .173

Knohl A, Schulze ED, Kolle O, Buchmann N (2003) Large carbon uptake by an unmanaged 250-year-old deciduous forest in Central Germany. Agric For Meteorol 118(3):151-167. doi:10. 1016/S0168-1923(03)00115-1

Lagergren F, Eklundh L, Grelle A, Lundblad M, Mölder M, Lankreijer H, Lindroth A (2005) Net primary production and light use efficiency in a mixed coniferous forest in Sweden. Plant Cell Environ 28(3):412-423. doi:10.1111/j.1365-3040.2004. 01280.x

Li ZQ, Xu JC, Shilpakar R, Ma X (2014) Mapping wetland cover in the greater Himalayan region: a hybrid method combining multispectral and ecological characteristics. Environ Earth Sci 71(3):1083-1094. doi:10.1007/s12665-013-2512-y

Lloyd J, Taylor J (1994) On the temperature dependence of soil respiration. Funct Ecol 8(3):315-323. doi:10.2307/2389824

Myneni RB, Ramakrishna R, Nemani R, Running SW (1997) Estimation of global leaf area index and absorbed PAR using radiative transfer models. IEEE T Geosci Remote 35(6):13801393. doi: $10.1109 / 36.649788$
Pan Y, Birdsey RA, Fang J, Houghton R, Kauppi PE (2011) A large and persistent carbon sink in the world's forests. Science 333(6045):988-993. doi:10.1126/science.1201609

Pan S, Tian H, Dangal SR, Ouyang Z, Tao B (2014) Modeling and monitoring terrestrial primary production in a changing global environment: toward a multiscale synthesis of observation and simulation. Adv Meteorol. doi:10.1155/2014/965936

Papale D, Valentini R (2003) A new assessment of European forests carbon exchanges by eddy fluxes and artificial neural network spatialization. Glob Change Biol 9(4):525-535. doi:10.1046/j. 1365-2486.2003.00609.x

Pourtaghi ZS, Pourghasemi HR, Rossi M (2015) Forest fire susceptibility mapping in the Minudasht forests, Golestan province, Iran. Environ Earth Sci 73(4):1515-1533. doi:10.1007/s12665014-3589-7

Propastin P, Ibrom A, Knohl A, Erasmi S (2012) Effects of canopy photosynthesis saturation on the estimation of gross primary productivity from MODIS data in a tropical forest. Remote Sens Environ 121(6):252-260. doi:10.1016/j.rse.2012.02.005

Rahman AF, Sims DA, Cordova VD, EI-Masri BZ (2005) Potential of MODIS EVI and surface temperature for directly estimating perpixel ecosystem C fluxes. Geophys Res Lett 32(19):L19404. doi:10.1029/2005GL024127

Reichstein M, Falge E, Baldocchi D, Papale D, Aubinet M (2005) On the separation of net ecosystem exchange into assimilation and ecosystem respiration: review and improved algorithm. Glob Change Biol 11(9):1424-1439. doi:10.1111/j.1365-2486.2005. 001002.x

Richardson AD, Anderson RS, Arain MA, Barr AG, Bohrer G (2012) Terrestrial biosphere models need better representation of vegetation phenology: results from the North American Carbon Program Site Synthesis. Glob Change Biol 18(2):566-584. doi:10.1111/j.1365-2486.2011.02562.x

Running SW, Nemani RR, Heinsch FA, Zhao M, Reeves M (2004) A continuous satellite-derived measure of global terrestrial primary production. Bioscience 54(6):547-560. doi:10.1641/0006-3568

Saigusa N, Yamamoto S, Hirata R, Ohtani Y, Ide R (2008) Temporal and spatial variations in the seasonal patterns of $\mathrm{CO}_{2}$ flux in boreal, temperate, and tropical forests in East Asia. Agric For Meteorol 148(5):700-713. doi:10.1016/j.agrformet.2007.12.006

Seiler TJ, Rasse DP, Li JH, Dijkstra P, Anderson HP (2009) Disturbance, rainfall and contrasting species responses mediated aboveground biomass response to 11 years of $\mathrm{CO}_{2}$ enrichment in a Florida scrub-oak ecosystem. Glob Change Biol 15(2):356367. doi:10.1111/j.1365-2486.2008.01740.x

Sims DA, Rahman AF, Cordova VD, El-Masri BZ, Baldocchi DD (2008) A new model of gross primary productivity for North American ecosystems based solely on the enhanced vegetation index and land surface temperature from MODIS. Remote Sens Environ 112(4):1633-1646. doi:10.1016/j.rse.2007.08.004

Sjöström M, Zhao M, Archibald S, Arneth A, Cappelaere B (2013) Evaluation of MODIS gross primary productivity for Africa using eddy covariance data. Remote Sens Environ 131(4):275286. doi:10.1016/j.rse.2012.12.023

Tan B, Woodcock CE, Hu J, Zhang P, Ozdogan M (2006) The impact of gridding artifacts on the local spatial properties of MODIS data: implications for validation, compositing, and band-to-band registration across resolutions. Remote Sens Environ 105(2):98114. doi:10.1016/j.rse.2006.06.008

Tang XG, Wang ZM, Xie J, Liu DW, Desai AR (2013) Monitoring the seasonal and interannual variation of the carbon sequestration in a temperate deciduous forest with MODIS time series data. For Ecol Manag 306(10):150-160. doi:10.1016/j.foreco. 2013.06.032

Turner DP, Urbanski S, Bremer D, Wofsy SC, Meyers T (2003) A cross-biome comparison of daily light use efficiency for gross 
primary production. Glob Change Biol 9(3):383-395. doi:10. 1046/j.1365-2486.2003.00573.x

Verma M, Friedl MA, Richardson AD, Kiely G, Cescatti A (2014) Remote sensing of annual terrestrial gross primary productivity from MODIS: an assessment using the FLUXNET La Thuile data set. Biogeosciences 11(8):2185-2200. doi:10.5194/bgd-10$11627-2013$

Wang X, Ma M, Li X, Song Y, Tan J (2013) Validation of MODISGPP product at 10 flux sites in northern China. Int J Remote Sens 34(2):587-599. doi:10.1080/01431161.2012.715774

Williams CA, Hanan NP, Baker I, Collatz GJ, Berry J (2008) Interannual variability of photosynthesis across Africa and its attribution. J Geophys Res. doi:10.1029/2008JG000718

Wu CY, Munger JW, Niu Z, Kuang D (2010) Comparison of multiple models for estimating gross primary production using MODIS and eddy covariance data in Harvard Forest. Remote Sens Environ 114(12):2925-2939. doi:10.1016/j.rse.2010.07.012

Wu C, Chen JM, Huang N (2011) Predicting gross primary production from the enhanced vegetation index and photosynthetically active radiation: evaluation and calibration. Remote Sens Environ 115(12):3424-3435. doi:10.1016/j.rse.2011.08.006

Xiao J, Zhuang Q, Law BE, Chen J, Baldocchi DD (2010) A continuous measure of gross primary production for the conterminous US derived from MODIS and AmeriFlux data. Remote Sens Environ 114(3):576-591. doi:10.1016/j.rse.2009.10.013
Yang FH, Ichii K, White MA, Hashimoto H, Michaelis AR (2007) Developing a continental-scale measure of gross primary production by combining MODIS and AmeriFlux data through support vector machine approach. Remote Sens Environ 110(1):109-122. doi:10.1016/j.rse.2007.02.016

Yuan W, Liu S, Yu G, Bonnefond JM, Chen J (2010) Global estimates of evapotranspiration and gross primary production based on MODIS and global meteorology data. Remote Sens Environ 114(7):1416-1431. doi:10.1016/j.rse.2010.01.022

Zhao M, Running SW (2010) Drought-induced reduction in global terrestrial net primary production from 2000 through 2009 . Science 329(5994):940-943. doi:10.1126/science.1192666

Zhao M, Running SW (2011) Response to comments on "Droughtinduced reduction in global terrestrial net primary production from 2000 through 2009”. Science 333(6046):1093. doi:10. 1126/science. 1199169

Zhao M, Running SW, Nemani RR (2006) Sensitivity of Moderate Resolution Imaging Spectroradiometer (MODIS) terrestrial primary production to the accuracy of meteorological reanalyses. J Geophys Res. doi:10.1029/2004JG000004 